\title{
Fashioning Archaeology into Art: Greek Sculpture, Dress Reform and Health in the 1880s
}

\section{Debbie Challis}

Drapery in sculpture and art has a function. It acts as clothing: as a way of both seeing and yet obscuring the figure. It draws attention to the body while covering it. It often lies next to a nude as fallen clothing. It plays a part in the narratives of sculpted story telling. It indicates how the female form should be seen and what parts of the body should be made visible through the draped veiling. Drapery has been an influential artistic conceit in the Western world since early antiquity and artists have revisited the form and function of drapery and the body since the early Renaissance. Gillian Clarke has argued that classical drapery is so prevalent in European art that "classicists tend to think of it not as clothing but as an example of Greek and Roman art" (105). Drapery has long been an 'artistic conceit', a device showing artistic flair and rendering. This is brought to an apogee in the large paintings by the contemporary artist Alison Watt. The contours of flesh hidden by the folds of cloth are searched for in vain as there is no body hidden. Alison Watt's work is a study of cloth, of folds, of voids, of form for its own sake. It is what Anne Hollander has referred to as empty drapery (36), or, perhaps more positively as Gen Doy ventures, arranged cloth as art (230). The natural instinct to look for the body beneath the drapes is dictated partly by the use of drapery to show off the body, particularly in the work of nineteenth-century artists. By the end of the nineteenth century, Greek sculpture and the clothed female form was being used in an ideological and social battle - the battle for the uncorseted body.

The influence of Greek sculptural ideals and Greek clothing are relatively well known, as is the connection between the aesthetic and Pre-Raphaelite artists and dress reform (Newton; Cunningham). The exhibition The Cult of Beauty. The Aesthetic Movement 1869-1900 at the Victoria and Albert Museum in 2011 made these connections through a display of clothing, dress manuals and other items. The Cult of Beauty also illustrated the influence of Greek clothing on contemporary art and dress reform through the display of two 'Tanagra' terracotta figurines, on loan from the British Museum, as part of the section on "Grecian Ideals." In 1879 the writer on fashion in clothing and furnishings Eliza Haweis included four sketches of these 'Tanagra' terracottas to illustrate how Greek women dressed using "numberless folds to both reveal and conceal the body" in her dress reform book The Art of Beauty:

How gracefully the dress followed the movements of the body, may be perceived better from the small coloured clay figures in the British Museum [Greek Room], than even from marble statues, for they represent their ordinary domestic manners and are not carefully posed and idealised goddesses. (46)

Dresses on display in The Cult of Beauty showed how there was an attempt to shape fabric to reveal natural contours through artful drapery and bodices with minimal or no boning (Ehrman 206).

The principal artists of the mid to late nineteenth century led a revival of classicism in painting and sculpture in Britain, which was a major influence on the theatre, decorative style and fashion in this period. However, it was the dramatic 
archaeological 'discoveries', which had been brought to public attention and benefited the British Museum, that created an atmosphere in which there was a desire to reconstruct or recreate ancient Greece visually. Kate Flint points to "the development of the visualisation of experience" that continues through the nineteenth century; linking this experience to the "more permanent display of material" in museums and the "growing number of art exhibitions" (3). This development of a "visualisation of experience" is crucial for understanding the reception of classical antiquity during this period. The Greek court at the Crystal Palace in Sydenham, along with the other Fine Arts Courts, is a good example of the desire to make the vision of antiquity corporeal and create an arena through which the past could be physically experienced and observed. Emphasis on accuracy in the staging and costumes of the plays performed in the $1880 \mathrm{~s}$, considered at the end of this article, was due to increased knowledge about the material culture of ancient Greece brought to light by archaeological excavation and museum display.

As this article will argue, these archaeological discoveries and the subsequent displays arising from them provided a new visual and material culture of archaeology that inspired a British re-fashioning both in clothing and identity. The work of imagining the impact of classical Greek dress - on the body, health, and national fitness - provoked new ways of considering British civilisation both in relation to the ancient world and to existing cultures of nationhood in the 1880s. In the dress reform movement, and in the use of costume for stage drama a new creative fashioning of Britishness (and especially female Britishness) emerged. It must be noted, however, that this imaginative renegotiation of what it meant to be British in light of recent archaeological discoveries was largely undertaken within a small group of intellectual and social elites. Those involved in both the dress reform movement and the promotion of Greek sculpture as representing the aesthetic and physical ideal included curators at the British Museum, such as Alexander Murray, Charles Newton and Reginald Stuart Poole; artists, such as G. F. Watts, Henry Holiday and Walter Crane; writers and figures of society, including Eliza Haweis, Oscar Wilde and his wife Constance. It was therefore in relatively small urban and academic circles that 'South Kensington Hellenism' flourished.

There was also a link from dress reform to physical fitness and a greater emphasis on health. Writers on dress and hygiene reform placed emphasis on the need for women to be fit and active for their roles as future mothers of a healthy nation and race of people. Pamela Gilbert argues in The Citizen's Body that the discourse of hygienic and sanitary reform was articulated as a form of control and was linked to greater socio-political questions:

The management of the social body through public medicine and discourses of health became the principal discourse with which to negotiate these new questions of citizenship and the Condition of England, of the fit individual and problematic masses. The development of this discourse identified the healthy body and healthy desires as the basis of political fitness. Over the course of this period, the citizen became not only a moral product of education but also a physical product of good domestic hygiene. (3-4)

Wearing a tightly laced corset for long periods is likely to damage the body and make pregnancy unsafe or difficult to achieve. Gilbert's Foucauldian argument around control and citizenship is a useful one in considering dress reform, while acknowledging that rational dress was a rebellious reaction against an unhealthy 
orthodoxy in fashion. Greek dress was considered to allow women's natural contours and shape to be revealed as well giving them more ability to move and be physically active. Charles Kingsley makes this point in his 1873 lecture "Nausicaa in London: Or, the Lower Education of Woman," in which he quotes the passage in The Odyssey in which Nausicaa plays ball with her female companions on the beach(62). J. Moyr Smith makes this explicit with regard to Greek clothing in his book Ancient Greek Female Costume in 1882: "Though more fully clad in most parts of Greece than in Sparta, the costume of the young girls and women was such as allowed the body to develop its natural beauty, and permitted a graceful freedom of motion" (17).

This promotion of unconstrained movement through rational or hygienic dress aroused the interest of the medical press and professionals as is made clear in the 1884 Health Exhibition. However, the ideal of Greek clothing revealing the fit body as illustrated in sculpture and other artworks was not simply an aesthetic style or a rational alternative to the corset. It was also an ideal related to the perceived physical perfection of the racially fit body as exemplified in Greek sculpture (Challis 2010).

\section{Grecian Robes}

Concern in artistic circles about the ugliness of contemporary dress was not new to the 1880 s or the aesthetic period. The toga-clad naval heroes in St Paul's Cathedral in London attest to the desire of neo-classical artists of the early nineteenth century to clad their subjects in more pleasing antique attire. The antiquarian collector and designer Thomas Hope (1769-1831) published books promoting classical design for the home and in dress, including Costumes of the Ancients (1809) and Designs of Modern Costumes (1812). During the late eighteenth and nineteenth centuries there is a strong classicism in fashion, particularly for women, and Hope's suggestions for clothing in his books exemplified high fashion at the time. Gen Doy has pointed out that critics writing on art and aesthetics since Johann Joachim Winckelmann in the mid eighteenth century have commented on the ugliness of modern dress. For example, Georg Hegel wrote that "Greek clothing is the ideal modem for sculpture and is to be preferred by far to the modern" (Doy 22). Pre-Raphaelite artists, and others, advocated dress along more classicising and medieval lines during the $1850 \mathrm{~s}$ and $1860 \mathrm{~s}$ (Cunningham 104). G. F. Watts' early portrait of Sophia Dalrymple (c. 1851-3) illustrates his admiration of her unusual taste in plain classical dresses and, as Barbara Bryant notes, "the thick folds of Sophia's dress corresponded to the drapery of antique sculpture, a touchstone for Watts" (83). Watts would return to this theme publicly in the 1880 s through an article advocating the wearing of classical influenced dresses designed to follow the natural forms of the female body.

A decade after this portrait the classicising style of costume became more pronounced in art through the paintings of various artists, such as Frederic Leighton, Lawrence Alma Tadema, Albert Moore and James McNeill Whistler. Elizabeth Prettejohn points to the classical influences in three paintings by Whistler (Symphony in White, No. III), Moore (The Musicians) and Leighton (Spanish Dancing Girl) all on display at the Royal Academy Exhibition in 1867:

Moreover, all three include classicising elements, such as clinging, intricately folded drapery and poses reminiscent of the Parthenon marbles, but without antiquarian strictness: Leighton's 'Spanish' dancing girl wears draperies that closely imitate classical Greek sculpture, with crossing cords and a heavy overfold at the waist; Moore's setting includes palm fans and a 'Japanese'looking spray of flowers; and Whistler's picture combines a Japanese fan with 
another asymmetrical spray of foliage and curious 'Regency'-style dresses, with high waists and puffed sleeves. (137)

The transparency of the body beneath the drapery is a clear reference point to the female reclining figures from the Parthenon pediment sculptures. This is obvious in Albert Moore's Beads (1875), which depicts two young women reclining asleep in different positions on a soft fabric bench with their legs, breasts, nipples and small folds of their stomachs clearly visible beneath their white diaphanous Greek clothes. Robyn Asleson points out that "the snaking movement of the drapery exaggerates the curves of the anatomy which is clearly seen beneath the transparent gauze fabric" (133). Similarly G. F. Watts' Ariadne in Naxos, now in the Guildhall Art Gallery London, from the same year depicts Ariadne sitting staring out to sea in rolls of draped Greek clothing showing the lines of her body but has less fleshy detail. In all these paintings the poses struck of young women curled up or languorously reclining would not have been possible in the corseted fashion of the period. These paintings rebel against the restraint of movement in modern clothing.

The Parthenon sculptures associated with the classical Greek sculptor Pheidias were increasingly influential and the influx of classical art into Britain through the mid nineteenth century, such as the sculptures from Nereid Monument in Lycia and the Mausoleum of Halicarnassus in Bodrum, only served to emphasise the importance attributed to Greek art (Challis, From the Harpy Tomb). The increased use of the Pheidian figural type in art works, classical history subjects and the depiction of everyday life in Greek and Roman antiquity was part of the classical revival of art that took place in Britain from the 1860s until the end of the nineteenth century. Athena Leoussi argues that nineteenth-century classicism was "the result of scientific positivism and specifically of the idealisation by the life sciences of the body of the ancient Greek athlete as healthy" (79), which became preoccupied with the physical health of the modern nation in comparison. The anthropological account of the ancient Greeks taken from ancient sculpture became the racial and physical ideal of modern Europeans in handbooks on art and physical development; Pheidian figural sculpture became the "embodiment of European type" (Challis, "The Ablest Race" 112). The athleticism and Greek styled modelling of G. F. Watts' Cecil Rhodes Memorial in South Africa has been read by Michael Hatt "with its nude hero celebrating what was for Watts the triumph of Aryanism in the Dark Continent" (43).

The depiction by Moore, Leighton and other artists of languorous women in Greek robes emulating classical sculpture placed greater emphasis on the female body as well as the male for the importance of the physical health of the nation. By the 1880s these artists and their interests were so well known as to be regularly parodied. For example, a cartoon "Art in Olympus: Or the Academia of the Gods," by Edward Linley Sambourne, in Punch in 1886 depicts Leighton as Zeus in the centre of Olympus, with caricatures of various artists taking the guise of different gods around him, such G. F. Watts as Saturn (see Fig. 1). All the artists are posed in front of the Acropolis with a nude female model attempting to cover herself in folds of drapery that reveal, rather than hide, her naked body. These 'Olympian' artists were responsible for creating an atmosphere in which Greek clothing was fashionable and adaptable to the arguments of dress reformers, as well as popularising the physical ideal depicted in Greek sculpture. 


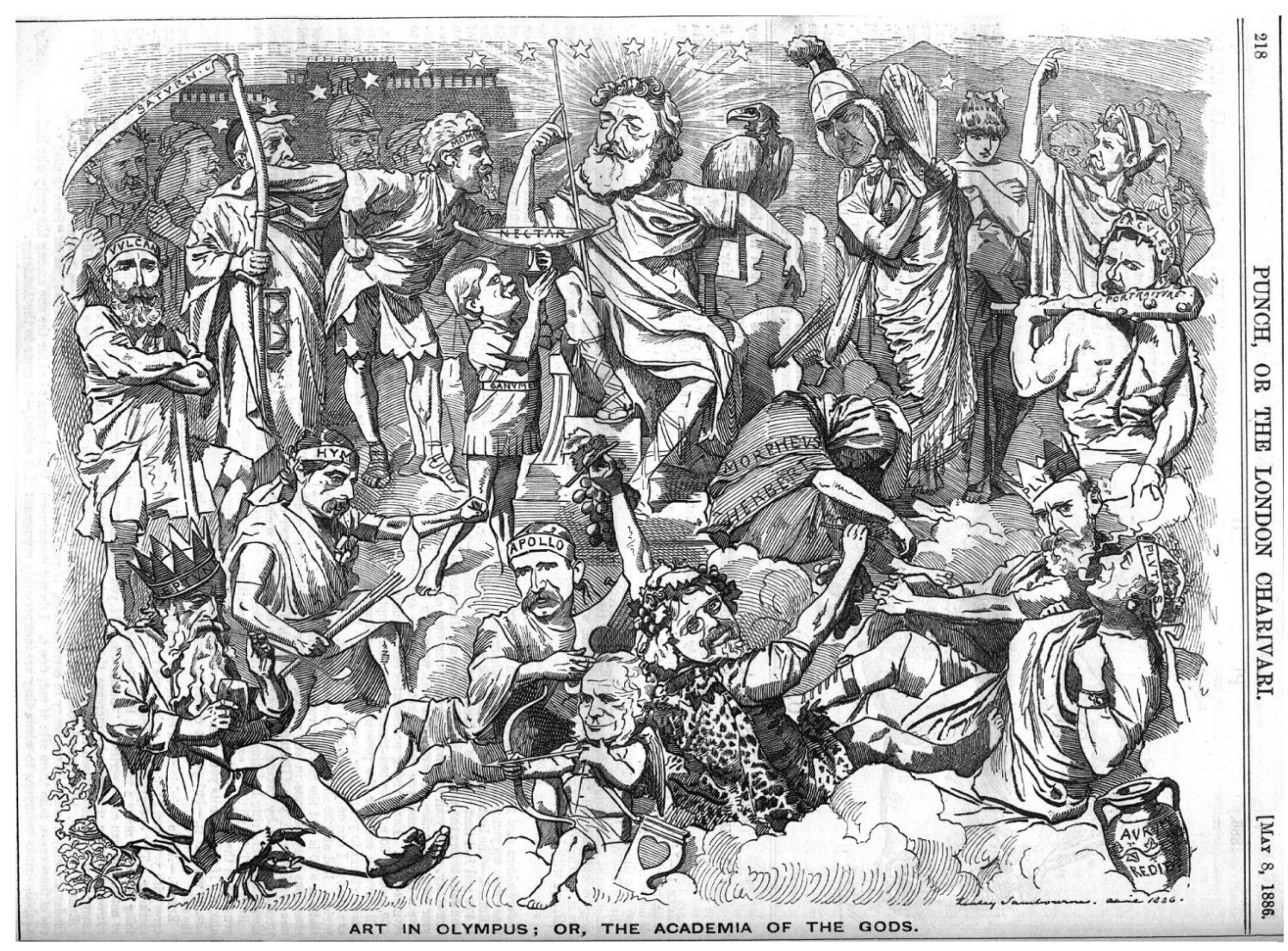

Fig. 1.

Linley Sambourne. "Art in Olympus; Or, the Academia of the Gods.” Punch 29 May 1886.

\section{Healthy Dress, Healthy Body}

While Greek forms in art reached new heights of popularity in the late 1860s and 70s, dress reformers were also becoming more vocal. Again, dress reform was not an entirely new crusade, for example the doctor Andrew Coombes wrote treatises on it as early as 1834 . By the late 1860 s the large domed skirts of the crinoline were out of fashion and instead the so-called 'S-shape' or Grecian bend became fashionable. (The 'S-Shape' was later used to describe the shape of the Edwardian corset in the 1900s). This shape thrust the breasts out to the front and pushed the buttocks out at the back with the ideas of transforming the wearer into "an unctuous version of the Winged Victory of Samothrace" (Newton 37). The illustrator Frederick Barnard published a cartoon in 1869 "'Oh Stay!' or, Graces versus Laces," unfavourably comparing the natural curves and waistlines of the Greek style Graces and Venus peering into a corset boutique which illustrated the ridiculous bodily form of the "Grecian bend' (Barnard 120). Charles Kingsley singled out the 'Grecian bend' for ridicule in "Nausicaa," deriding its 'Grecian' epithet and pouring scorn on the 'chignon' (or hair-piece designed to make the hair look bigger at the back), hats and shoes that went with the fashion.

Dress reform was part of a wider movement around sanitary conditions and healthy living. Charles Kingsley's lecture "Nausicaa in London" on dress reform opens with his musings upon visiting the British Museum:

Fresh from the Marbles of the British Museum, I went my way through London streets. [. . .] Above all, I had been pondering over the awful and yet tender beauty of the maiden figures from the Parthenon and its kindred 
temples. And these, or such as these, I thought to myself, were the sisters of the men who fought at Marathon and Salamis; the mothers of many a man among the ten thousand whom Xenophon led back from Babylon to the Black Sea shore; the ancestresses of many a man who conquered the East in Alexander's host, and fought with Porus in the far Punjab. (58)

The emphasis is clear; the natural female forms Kingsley has seen in the British Museum belong to the mothers and sisters who have bred the greatest civilisation in the world. Kingsley compares the sculpted female forms to the contemporary ugliness he sees on the streets around him, which he condemns; advocating a form of physical education for young women as well as the wearing of less bodily restrictive clothing. Arguably, Kingsley's ideas on the physical education of young women to equip them better for motherhood and a healthy life correspond to Gilbert's reading of defining health in the mid-nineteenth century as a set of hygienic practices appropriate to middle-class tastes with domestic life seen as the perfect conduit for bridging national identity between the population as a whole and the individual(8). Kingsley argues that adapting Greek games for women will enable them to "earn the gratitude of the patriot and the physiologist" by improving their "physique, and therefore ultimately of the morale, in the coming generation of English women" (73). Greek dress, it is stressed allowed women to show their natural curves and carry out physical exercise with a view for preserving and enhancing future generations.

Dress reformers also supported Kingsley's arguments. Eliza Haweis commented a few years later in her book The Art of Beauty (1878) that "no generations of care have made the British body beautiful like the Greeks was" (33). In her chapter "What Stays Costs Us," Haweis depicts a tyrannical corset and its affect on the ribs and spine and organs deforming the body, compared to the natural figure seen in the Greek sculpture of Venus (48).

Dress once expressed the person, it now disguises it; well, disguise may sometimes be necessary - but when dress carried its anatomical fictions as far as evasion may be carried, as far as falsehood, it ceases not only to be respectable, but beautiful as well. (17)

Similarly G. F. Watts argued in his article "On Taste in Dress," first published in Fortnightly Review in 1883, that the Greek canons of human proportion were perfect and so small waists in women created by the corset were not natural (Watts 203). Watts' stance was supported by Ada S Ballin three years later in her The Science of Dress:

If our girls were taught the laws of health and a few of the principles of art as known to the ancient Greeks, they would soon see 'what a deformed thief this fashion is,' and would laugh at the squeezed in waist, the crinolette, and the foot mangles and crushed by high heeled and pointed boots of recent times, as much as we now, who call ourselves civilised, ridicule the Australian with his nosepeg, or the Bongo negro, who drags his lips down with a plug. (3)

Ballin juxtaposes ideas of barbarism and civilisation, comparing different forms of clothing and fashion that are all inferior and less 'civilised' than the Greeks. Ballin warned against tight lacing in pregnancy and stays for nursing mothers: 
[Stays] not infrequently hinder the development of the breasts to such an extent that they render it impossible for many mothers to perform their natural duties to the young infants who are dependent on them for the only nourishment which is suitable and wholesome for them. (165)

The naturalness of Greek clothing for the well-being of the body is equated with the naturalness of motherhood and the wholesome health of future generations. The dress and the flowing forms of drapery depicted in Greek sculpture are equated with the practice of real women and the achievements of ancient Greece.

\section{Greek Dress in Practice}

Despite this idealisation of Greek clothing, there were limitations on how much it could be practically applied. Eliza Haweis noted that Greek clothing was not suitable for the British climate, nor for most women due to their physical differences to the ancient Greeks:

Some adaptation of the Greek dress, the most perfect of known costumes has been suggested as meeting all needs. The simple Chyton would be pretty enough for young and finely moulded women, but for the many it would be too trying and monotonous. Robust and lovely as is the pure English type, the race is too mixed as I have said to endure one costume; long-limbed and shortlimbed, the small waisted and the heavily built, could not be equally set off by such a dress, any more than fair and dark can submit to one colour. The Greek pallium, sufficiently padded to brave an English winter, would be too heavy to be popular, and far too expensive for the poorer classes. (27)

Despite this the designer John Moyr Smith published Ancient Greek Female Costume in 1882, which included an informative essay and 112 drawings taken from Greek sculpture in the British Museum and the Louvre. Such detailed descriptions of ancient Greek female dress influenced designs for aesthetic dress. 'Tadema tea gowns', influenced by the 'Victorian in togas' paintings of Lawrence Alma-Tadema and worn at home as informal wear, became fashionable in society from the late $1870 \mathrm{~s}$. A review of aesthetic dress in Harper's Bazaar in November 1881 shows one dress in the neoGreek style that "combines the classic characteristics with the requirements of modern fashion" set off by an "Etruscan gold necklace and bracelets being a reproduction of the gold ornaments excavated by Professor Schliemann" (Blum 129). Moyr Smith reproduced drawings of a gold diadem and bracelet, found by Schliemann at Mycenae and Troy respectively, as testament to the "great skill of the Greek, Phoencian or Trojan jewellers" and referred to Schliemann's volumes Mycenae and Ilios (Moyr Smith 51). Clearly there was enough commercial interest to make replica jewellery.

The enthusiasm for Greek art and aesthetics was significant enough to be mocked in Punch, as well as other periodicals, and was also part of the aesthetic movement satirised in Gilbert and Sullivan's opera Patience (1881). For example, a cartoon by George du Maurier appeared in Punch in 1880 depicting a group of admiring women listening to the dandified art critic Prigsby comparing a head in a painting to Greek sculpture. The satire is as much directed at the pretentious female admirers as the aesthetic art critic. ${ }^{2}$ In other cartoons Du Maurier was ambivalent about aesthetic dress and in "An Impartial Comment" unfavourably contrasted the unhealthy thin waist and corset that was high fashion to aesthetic dress. In $1883 \mathrm{H}$. D. Trail satirised the enthusiasm for all things ancient Greek in an article for the Fortnightly 
Review titled "South Kensington Hellenism: A Dialogue between Plato and Lander." Trail targets South Kensington due to the 'Hellenic' lectures taking place at the South Kensington Museum and the rehearsals for a Greek influenced drama, The Tale of Troy, taking place nearby. In reference to the revival of Greek drama that was beginning, Landor proclaims "their Hellenism is a sham product redolent of that modern and modish suburb in which its latest festival was held" (118). Traill's critique is directed at the Olympian artists and Hellenists behind the revival of Greek tragedy, and appears to be mainly directed at "the enthusiasm of young women." His attack and that of du Maurier's can be attributed to as much misogyny as to any cultural criticism.

The private production of George Warr's Tales of Troy; or Scenes and Tableaux from Homer (Warr was professor of Greek at King's College, London) that Traill referred to was performed in Greek and English in the private house of the builder Sir Charles and Lady Freake in South Kensington in 1883. Charles Newton, Keeper of the Department of Greek and Roman Antiquities at the British Museum, advised on props and costume, even lending his house in Bloomsbury for the female members of the cast to be "coached in their Greek by Professor Warr, each and all became the willing slave of Watts and [John] Millais, Tadema, [Edward] Poynter and [Edward] Burne-Jones who flung themselves into the task of supervising scenery and costume" (Beard 38). Newton apparently directed some scenes of the play himself and in rehearsals "decked them (the actors) out in the appropriate, archaeologically bona fide ornaments" (Beard 52). Charles Waldstein helped coach the ladies in Greek, while the daughter of Reginald Stuart Poole (Keeper of Coins and Medals at the British Museum) was responsible for costume (Mirrlees 1). Two students and lecturers at the British Museum, Jane Harrison and Eugénie Sellars were among the female cast members (Sellars playing Helen in English and Cassandra in Greek and Harrison playing Penelope). The performance in Greek was staged to raise money for King's College extension lectures for ladies, as Charles Newton's lectures on Greek Art at UCL in 1880 had aimed to do for University College London. Warr had lectured in Ancient History at the South Kensington Museum in 1879, in a series of lectures for ladies. It is therefore ironic that one of the main criticisms of the performance in the Illustrated London News is the Greek pronunciation by the predominantly female cast.

The magazine does not reproduce any scenes but gives a "few examples of Greek female costume, with the portraits of several gentlemen engaged in the business of this performance" ("Greek Plays" 547). Leighton is pictured surrounded by ladies in Hellenic dress and Newton is in the top left-hand corner. The women are defined by costume not their performance or personality. An image of the play from the Illustrated London News show, or rather 'display', the women in classical costume, apart from the servant who is pictured holding drapery rather than wearing it (See Fig. 2 ). The men, bar one, are in formal nineteenth-century dress illustrating their distinctiveness from the women surrounding them. The Illustrated London News image illustrates interest in classical costume, both as fashion commodities and as examples of 'artistic' dress. This stress on draped dress is also part of a wider artistic representation of women in drapery, acting as voyeuristic fantasies of women clothed but in diaphanous drapery, unshackled by corsets. This image from the Illustrated London News is arguably representative of the depiction of women and the female body in the late nineteenth century. On the one hand it illustrates an interest in the revival of Greek theatre and on the other it fetishizes the natural free flow of drapery on the female body, treating the women as sexualised anatomical models. 


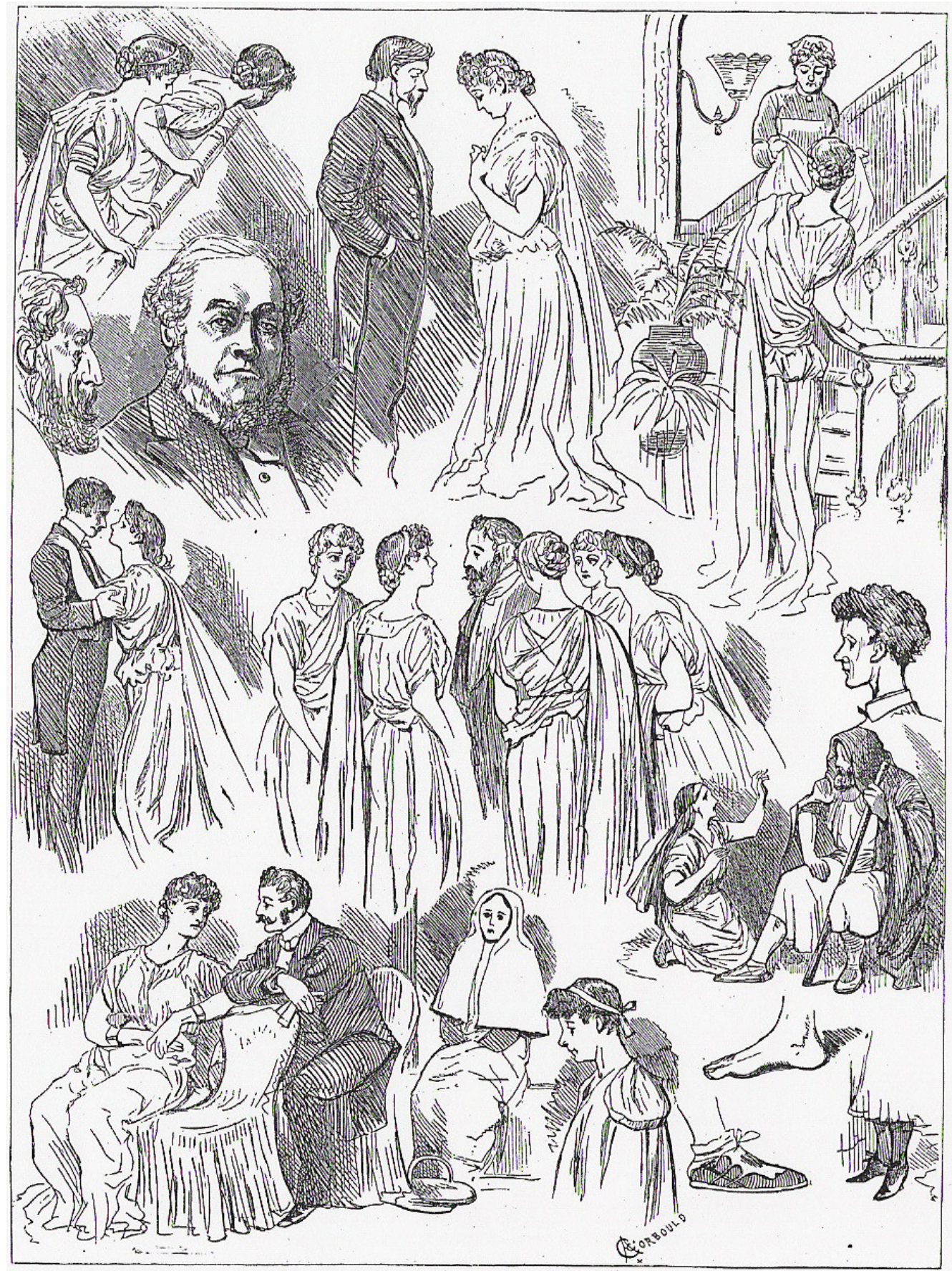

Fig. 2.

"Greek Plays." Illustrated London News 22 May 1886.

In the same year the Rational Dress Association put on an "Exhibition of Rational Dress," which showed practical examples of rational dress including a "Greek fancy dress" by I. H. Nathan, an Egyptian and a Japanese costume lent by Frank Dillon and catalogue entry one was a selection of art fabrics from the shop Liberty:

No. 1 Liberty's Art Fabrics 
Messr's Liberty have made it their special study to revive the materials so much in favour with ancient Greece, having at the same time due regard to the requirements of modern times. (King)

'Arabesque' dress and Japanese dress and fabrics were also influential on the rational dress movement. A section on dress and costume formed part of International Health Exhibition in 1884, which was held on the exhibition buildings around the Albert Hall in South Kensington and covered home, food, sanitation for all classes as well as dress. The Exhibition was a great success, being prolonged from its closing date of 1 August to October, and was popularly known as the 'Healtheries' (Newton 92). As well as having a section on rational dress and on costumes through history, the designer Edward W. Godwin addressed the Health Exhibition of 1884 on hygiene and beauty in dress, promoting the adaptation of Greek style dresses over woollen undergarments. In the same year Godwin was asked to direct the new Costume Department at Liberty and adapted past costumes to modern needs, including interpretations of Greek clothing (Adburgham 63). Godwin, along with G. F. Watts was also a member of the Anti-Tight Lacing Society.

The Exhibition and "Group 2 - Dress" was reviewed by the medical press, including The Lancet and British Medical Journal. Much of The Lancet's review is taken up with an overview of the historical costumes, commenting that tight lacing does not appear to be as bad in the past as it is now, and of the firms who have supplied clothes designed for safety use, such as for firemen (33). The section exhibited by the Rational Dress Society showed 'divided skirts,' clothes for athletics and appeared to be essentially the same as their exhibition of the previous year. Even the Official Guide to the exhibition noted that the display had "more reason than artistic sense" and considered that the "prejudices of fair sex [caused] considerable difficulties to their subjects" (31). The Lancet also noted the models showing deformities caused by dress, and in particular tight lacing, as well as exhibits by the Sanitary Woollen System Co. (Dr Jaegar) illustrating the hygienic benefits of wool next to skin. The interest of the medical press illustrated the interest of the medical profession in 'rational dress' for women. Dr George Wilson had written Healthy Life and Healthy Dwellings. A Guide to Personal and Domestic Hygiene in which he promoted Greek gymnastics for women in order to improve the physique of future generations as well as adapting Greek and Roman dress for modern use (Newton 92). In this way artistic, medical and reformist attitudes converged around Greek dress and the healthy and most beautiful body.

There was a return to Greek theatre a few years later with George Warr's abridgement of the Oresteia, which was performed twice at Prince's Hall with one performance of the Tale of Troy in 1886. The proceeds of these performances went towards extension lectures for women at Kings College and University College, University of London. Charles Newton again acted as archaeological advisor. The scenery was put together by Walter Crane from sets previously designed by Frederic Leighton, G. F. Watts and Henry Holliday for a tableau at the Hellenic themed Royal Academy Ball of the previous year. Crane and Warr published an illustrated translation of the plays in Echoes of Hellas, in which many of the illustrations were based on the stage sets and performances of Tales of Troy and the Story of Orestes. More important in terms of theatre practice and public impact, however, was Helena in Troas, a pastiche by John Todhunter and staged with a mixture of professionals and amateur actors in the same year. Helena in Troas was performed at Hengler's Circus on Argyll St, usually the home of a horse circus, and was turned into as near a copy of an ancient Greek theatre as possible. Edward W. Godwin, who had lectured on dress at the 
'Healtheries,' produced a play performed in 'the round.' Alexander Murray, now Charles Newton's successor as Keeper of the Department of Greek and Roman Antiquities at the British Museum, acted as archaeological adviser. Murray, in a letter to Godwin, Murray points out that Greek theatre was a semi-sphere but makes suggestions for a performance in the round (Murray). This was the first attempt in Britain at reproducing a Greek theatre with a similar use of stage space as the ancient Greeks. Casts of bas-reliefs from the Theatre of Dionysus in Athens and casts from the frieze of Bassae (on display in the British Museum) were incorporated into the set. This design may have been influenced by Richard Wagner's concept of Gesamtkunstwerk; a total work of art which combines music, poetry, dance, stage modelling and costume. The Festspielhaus at Bayreuth, erected by Otto Brockwald, followed an amphitheatrical design influenced by Wagner's adulation of Greek tragedy (Pitenis 159). The setting of Hengler's Circus was also due to the vogue for the archaeological costume drama depicted in so many paintings and the increased knowledge about the material culture of ancient Greece (see Fig. 3).

Godwin was responsible for the set and costume, and his designs enabled enough stage space for a large chorus, another attempt at reviving an authentic reproduction of Greek visual experience. Godwin made notes on each costume and character, for example Helena (played by Miss Alma Murray) wore a fawn colour tunic, a gold metal flat girdle, a white mantle with bands of decoration, gold sandals, her hair was weaved with gold fillets, gold earrings and a snake amulet. All this information reveals the care taken over the costumes, which was related to Godwin's promotion of Greek dress as healthy and artistic. Photographs in the Theatre Museum archive show Godwin's designs rather incongruously recreated in the English countryside. The actor Beerbohm Tree played Paris, while Constance Wilde, an amateur, was a chorus leader. Dorothy Dene, Leighton's model and an aspiring actress, was also among the cast. Despite the setting of the play in Troy and Schliemann's recent high profile excavations, Godwin wrote in the programme that the play was firmly positioned in the style of fifth-century BC Greece: "My intention has been to give the story staged surroundings like those which I suppose a play on such a subject may have received at Athens or Corinth in the days of Sophocles" (Godwin). ${ }^{3}$ 


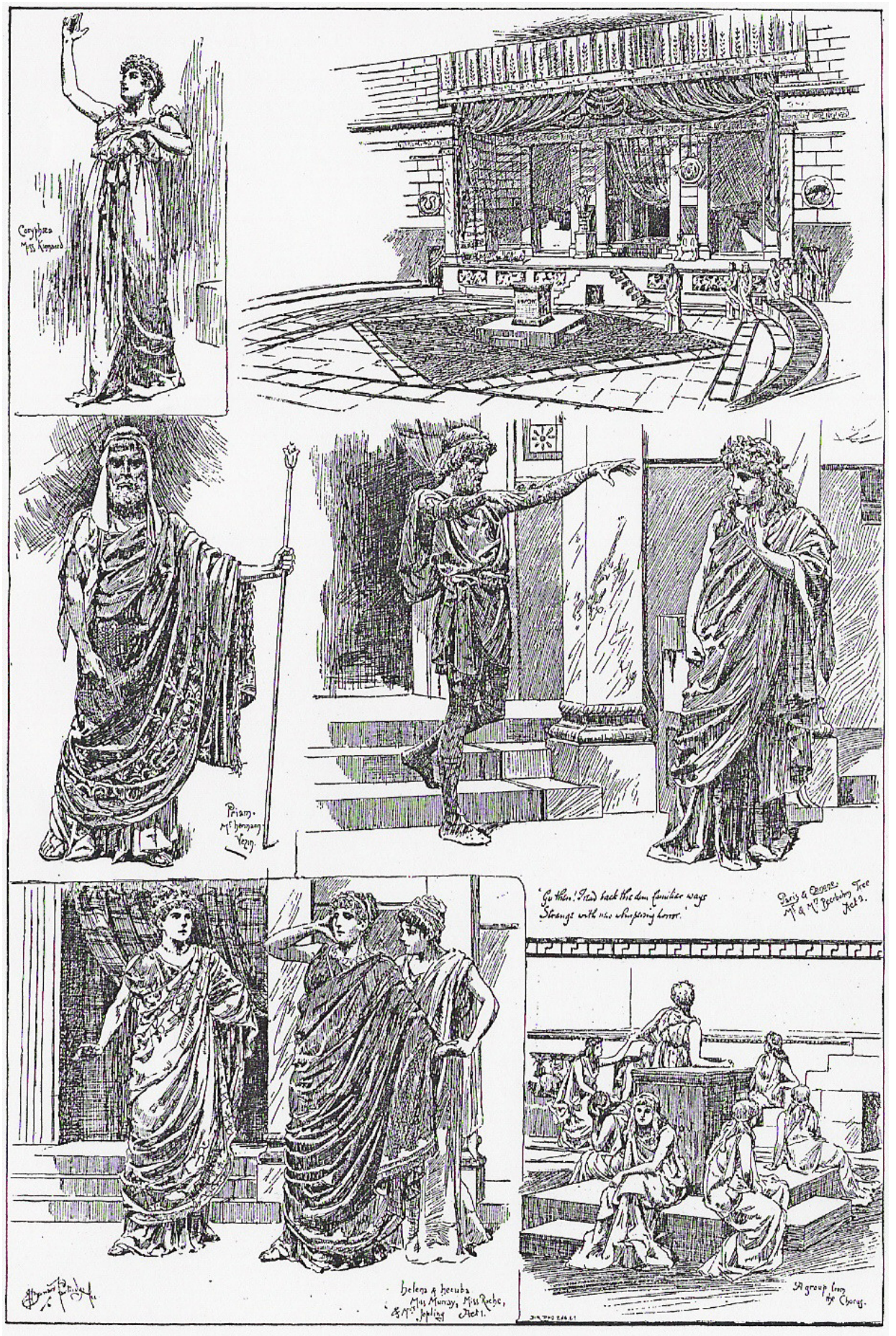

Fig. 3.

"Helena in Troas." Illustrated London News 29 May 1886.

Reviews in the Athenaeum, The Times, Morning Post, Standard Saturday Review and Illustrated London News for Helena in Troas concentrated on the accuracy of the set and costume, drawing attention to the visualisation of classical Greece rather than the performance or acting (daily papers tended to be more positive than the weekly journals). Punch mocked this chorus in "classic bathing costumes" looking "limp, but classic to the last" ("Mr Todhunter's Helena" 261). The Illustrated London News commented on the performances of the Greek plays: 
The archaeologists are revelling just now in the fields of Grecian art. Eminent members of the Royal Academy are arranging tableaux vivants from the old Homeric legend: distinguished authorities at the British Museum are consulted as to what Aeschylus or Sophocles would have done had either been commissioned to write a play for an Athenian Manager, a modern horse circus is turned into a theatre as it might have stood on the Acropolis. ("Greek Plays" 524)

Many of these distinguished authorities and artists attended the performance on the first afternoon, including Lord Leighton, Sydney Colvin, Charles Newton as well as figures from the theatre such as Henry Irving, Ellen Terry and Oscar Wilde. Wilde unsurprisingly, given his wife was chorus leader, gave the production a glowing review in the Dramatic Review and commented that Godwin turned the facts of archaeology in to "art" (161). Despite reservations about the script and acting, the next issue of the Illustrated London News included a full page spread of five illustrations from the performance of Helena of Troas, with an emphasis on the set and theatre. Both the Illustrated London News and Athenaeum advised readers to go to special performances of the play put on for the benefit of the British School of Athens, which began operations later that year ("Greek Plays" 564). Helena in Troas was a vivid example of the desire for visualising ancient Greece in the late nineteenth century and promoting Greek influenced aesthetic style and healthy fashion.

\section{Aftermath: Aglaia}

This promotion of the healthy body immortalised in Greek robes continued into the 1890s, during which time mainstream fashion demanded ever smaller waists. In 1893 the short lived magazine Aglaia: The Journal of the Healthy and Artistic Dress Union was published and edited by the artist Henry Holiday. This journal was produced by the Union for the Propagation of Sound Ideas on the Subject of Dress, which was founded 2 July 1890. The cover of Aglaia depicted the three Graces in flowing Greek dress by Henry Holiday, who wrote in the Introduction that:

Dress is needed for play as well as for work, and above all it should be healthy, so that we seek the aid of all the Graces. Thalia, moreover, was a Muse as well as a Grace - the pastoral Muse - and presided over an occupation as indispensable to us as to the primitive peoples of our race, which provides us with our best and healthiest form of raiment. (3)

Later in "The Artistic Aspect of Dress," Holiday wrote that the best dress belonged to the Greeks in the classic period and European nations from the twelve to fourteenth centuries: classical and medieval dress, as was of course then fashionable in PreRaphaelite art. Holiday published drawings showing distortion caused by a corset on models in artistic positions based on Greek sculpture entitled "Nature Proposes, But the Corset Disposes." Holiday connected the body of the ancient Greeks to the artistic and architectural symbols of their civilisation, writing that harmony nature has provided "he can adorn nature with his works, as the Athenians did when they erected the Parthenon and Propyleia on the Acropolis" (Holiday 30). This first copy of Aglaia also had a doctor, W. Wilberforce Smith, writing on "Corset Wearing: The Medical Side of the Attack" in which he warned of the impact of corsets on healthy conception and pregnancy: "This unmeasured damage to fitness, handicapping women in the race 
of life and hindering them in performing the best and noblest offices of their sex, probably constitutes the greatest of the evils of corset-wearing" (7).

Medical, hygienic and artistic views again coalesced, but appeared to have limited impact on mainstream fashion. There were only another two issues of Aglaia in 1894 and though they included articles and art work by Hamo Thornycroft. G. F. Watts, Walter Crane, Albert Moore, the actress Lily Linfield and retailer Lasenby Liberty, the magazine clearly had a limited circulation.

The main impact of the idealisation of Greek sculpture and the figural form as shown through drapery and rational dress is still to be found in the art of the period, rather than in any discernible change in mainstream fashion. Practical changes were made due to an increased number of women working and playing various sports, such as lawn tennis and cycling, and such change rapidly increased during World War One. However, a teaching kit in the archives of the former cast gallery at the University of Liverpool gives an intriguing glimpse of the increased importance placed on clothing for understanding the form and function of Greek sculpture and the domestic lives of the ancient Greeks. Models of Greek Dress for Lay Figures was produced by The Educational Museum of the Teacher's Guild of Great Britain and Ireland on 74 Gower St WC in 1896 and includes one hand written book and A Catalogue of the Historical Section. It sold at $11 \mathrm{~s}$ and gave examples of the dresses and directions for use in order to instruct children on Greek art and Greek domesticity, including replicas of an Ionic Chiton, Short Doric Chiton, Long Doric Chiton Himation and Chlamys. It shows the seriousness with which dressing up was taken, but it is also revealing of the continuation of the cultural importance of archaeological discovery on future generations of Britons, and especially British women.

Indeed the artistic, social, and medicalised responses to the discovery and display of Grecian antiquities show that turning archaeology into art offered far more than a creative outlet for understanding ancient sites far removed from Britain. Instead the material culture of ancient Greece allowed for an imaginative reconsideration of Britain itself, and especially of the British body and the manner by which it signified the robustness of a healthy, civilised body politic. 


\section{Notes}

With thanks for expert advice from Daniel Milford-Cotton, Victoria and Albert Museum, London.

1. These terracotta figurines are called 'Tanagra' after the site in Boeotia, Greece, where great numbers have been found. They became popular at the end of the Fourth Century BC and are in fact found throughout the Hellenic world over the next three centuries.

2. Reproduced in Ormond, 255.

3. The designs and photographs for the play can be seen in the Theatre Museum archive. 


\section{Works Cited}

Adburgham, Alison. Liberty's: A Biography of a Shop. George Allen and Unwin: London, 1975.

Asleson, Robyn. Albert Moore. Phaidon: London, 2000.

Ballin, Ada S. The Science of Dress in Theory and in Practice. London: Gilbert and Rivington, 1885.

Barnard, Frederick. "Oh Stay; or, Graces versus Laces" (1869). Exposed: The Victorian Nude. Ed. Alison Smith. Cat No. 51. London: Tate Publishing, 2001, 120.

Beard, Mary. The Invention of Jane Harrison. London: Harvard UP, 2000.

Blum, Stella, ed. Victorian Fashions and Costumes from Harper's Bazar 1867-1898. Dover: New York, 1975.

Bryant, Barbara. G. F. Watts' Portraits: Fame and Beauty in Victorian Society. London: National Portrait Gallery, 2004.

Clarke, Gillian. Women in Late Antiquity. Oxford: Oxford UP, 1993.

Cunningham, Patricia. Reforming Women's Fashion, 1850-1920. Politics, Health and Art. Ohio: Kent State UP, 2002.

Challis, Debbie. "The Ablest Race': Ancient Greek Art and Victorian Racial Theory." Classics and Imperialism in the British Empire. Ed. Mark Bradley. Oxford: Oxford UP, 2010: 94-120.

---. From the Harpy Tomb to the Wonders of Ephesus: British Archaeologists in the Ottoman Empire. London: Duckworth, 2008.

Doy, Gen. Drapery: Classicism and Barbarism in Visual Culture. London: I.B. Tauris, 2002.

Ehrman, Edwina. "Women's Dress." The Cult of Beauty: The Aesthetic Movement 1860-1900. Eds. Stephen Calloway and Lynn Federle Orr. London: V\&A, 2011. 206-7.

Flint, Kate. The Victorians and the Visual Imagination. Cambridge: Cambridge UP, 2000.

Gilbert, Pamela K. The Citizen's Body: Desire, Health and the Social in Victorian England. Columbus: Ohio State UP, 2007.

"Greek Plays." Illustrated London News 22 May 1886: 524.

Godwin, Edward W., "Programme Notes, Helena in Troas." MS. Godwin MSS, Box 8 "Helena in Troas." Theatre Museum, V\&A Archives, London.

Hatt, Michael. "Thoughts and Things: Sculpture and the Victorian Nude." Exposed: The Victorian Nude. Ed. Alison Smith London: Tate Publishing, 2001. 36-49.

Haweis, Eliza. The Art of Beauty. New York: Harper and Brothers, 1878.

"Helena in Troas." Illustrated London News 29 May 1886. 565.

Holiday, Henry. "Introduction." Aglaia: The Journal of the Healthy and Artistic Dress Union 1 (1893): 13-30.

Hollander, Anne. Seeing Through Clothes. Berkeley: U of California P, 1993.

"International Health Exhibition: Group 2 - Dress." The Lancet 5 July 5 1884: 32-34. International Health Exhibition: Official Guide. London: William Clowes and Sons, 1884.

King, E. Exhibition of Rational Dress. London: n.p.,1883.

Kingsley, Charles. "Nausicaa in London; Or, the Lower Education of Woman." Health and Education. London: W. Isbister, 1874. 58-73. 
Leoussi, Athena. "Nationalism and the Antique in Nineteenth-century English and French Art." The Uses and Abuses of Antiquity. Eds. Michael Biddiss and Maria Wyke. Bern: Peter Lang, 1999. 79-106.

Mirrlees, Hope. Jane Harrison Biographical Drafts \& Notes, Chapter IX: London in the Eighties. MS. Harrison Archive, JH Box 15, 4/3/4. Newnham College, Cambrdge.

Murray, Alexander. Letter to E. W. Godwin. 20 March 1886. MS. Misc. Correspondence in MSS, Godwin (1874-1885), Box 8 "Helena in Troas." Theatre Museum, V\&A Archives, London.

Moyr Smith, J. Ancient Greek Female Costume. London: Sampson Low, 1882.

"Mr Todhunter's Helena in Troas at Hengler's Circus." Punch 29 May1886: 261.

Newton, Stella Mary. Health, Art and Reform: Dress Reformers of the Nineteenth Century. London: John Murray, 1974.

Ormond, Leonée. George Du Maurier. London: Routledge \& Kegan Paul, 1969. 255.

Pitenis, Michalis. "The Influence of Ancient Archetypes on the Architecture of $19^{\text {th }}$ and $20^{\text {th }}$ Century Theatres." A Stage for Dionysos: Theatrical Space and Ancient Drama. Athens: Kapon Editions, 1998. 155-167.

Prettejohn, Elizabeth. Art for Art's Sake: Aestheticism in Victorian Painting. London: Yale UP, 2007.

Rossetti, William Michael and Algernon Charles Swinburne. Notes on the Royal Academy Exhibition, 1868. London: John Camden Hotten, 1868.

Sambourne, Linley. "Art in Olympus: Or the Academia of the Gods." Punch 29 May 1886: 218.

Smith, W. Wilberforce. "Corset Wearing: The Medical Side of the Attack." Aglaia: The Journal of the Healthy and Artistic Dress Union 1(1893): 7.

"The Tale of Troy." Illustrated London News 2 June 1883: 547.

Traill, H. D. "South Kensington Hellenism: A Dialogue Between Plato and Landor." Fortnightly Review 34 (1883): 111-119.

Watts, G. F. "On Taste in Dress." George Frederic Watts. Vol. III. His Writings. Ed. M. S. Watts. London: Macmillan, 912. 202-206.

Wilde, Oscar. "Helenea in Troas." The Dramatic Review. A Journal of Theatrical Musical and General Criticism. 3.69 (1886): 161. 